\title{
Prevention of lumbar disc herniation in young adult population - Collecting data for the awareness campaign
}

\author{
TEOIBAS-SERBAN Doroteea ${ }^{1}$, IORDACHE Liviu' ${ }^{1}$, STAN Valentin ${ }^{2}$, BLENDEA Dan ${ }^{1,2}$
}

Corresponding author: TEOIBAS-SERBAN Doroteea, E-mail: doroteeateoibas@yahoo.com

1. Clinical Regional Emergency Hospital Ilfov Bucharest, Romania 2. Univeristy of Medicine "Titu Maiorescu" Bucharest, Romania

\begin{abstract}
Introduction. Our previous paper discussed the increasing number of young adult population with lumbar disc herniation in the past few years. Most of the patients who seek medical attendance are young healthy male adults. They workout at the gym for a variety of reasons such as weight loss, muscle toning and increasing muscle mass. They are either unaware of the risk that certain exercises involve, or they wish to get faster results, obtaining the opposite effects. Thus, many of them develop lumbar disc herniation at a young age and must maintain certain restraints in order to stop it from evolving or reoccurring. The ideal solution is to increase awareness at the already numerous young male population who frequents the gym to prevent disc herniation. Material and method. The next step for our awareness campaign is to collect data directly from the source. A carefully created questionnaire with specific questions related to general knowledge, way of training and individual research on the topic was given to young adult males in many gyms from Bucharest. The questionnaire was completely anonymous and targeted young adult males which had to respond truthfully and give away only their age. Results and discussions. The statistics show that most of the responders to the questionnaire did know about lumbar disc herniation and the risk involved in exercises such as weightlifting but did not possess the proper knowledge of how to do certain movements in order to prevent it. Conclusions. The data collected showed that most of the young male adults which frequent the gym are not fully prepared with enough knowledge in order to do certain exercises without risking lumbar disk herniation. We must continue our campaign of awareness in this category of population in order to reduce the number of young patients with this disease.
\end{abstract}

Keywords: lumbar disc herniation, gym, low back pain, exercises,

\section{Introduction}

Lumbar disc herniation is a common increasing disease for all age categories. Some researches show that this ailment is more common in the age group between 30 to 50 years old with a sex difference ratio of 2 (male) to 1 (female). (1) Other recent studies however affirm that disc herniation is more and more common in the young adult population, as early as 20 years-old in both male and females and the most affected levels are L4-L5 and L5-S1. (2) Another studied theory shows that the risk of developing a disc herniation decreases since the age 65 more and more while approaching 90 years of age. (3)

There is some evidence that family history is the biggest risk factor for lumbar disc protrusion, and the next risk factor was lumbar load for patient younger than 55 years old. (4). Also, there is some discussion about the tissue composition of the herniated material difference between age categories. This theory adopted the idea that granulation tissue and neovascularization were increased in patient under 50 years old, whereas older patients have a more pronounced fibrous tissue in the herniated material (5). This evidence corelates with increased cases of neovascular tissue in children and adolescents in different areas than the intervertebral disc. $(6,7,8)$

The gender difference in disc herniation might also be due to OPRM1 genotype, which is known to promote the glycosylation of receptors - responsible for ligand binding - and associated with radicular pain and disc herniation. The different levels and types of glycosylation in men and female can be a reason for the sex ratio in disc herniation. (9)

One of the most corelated factor to herniated disc and particularly lumbar disc hernia is abnormal activities and weightlifting. It is shown that repetitive bending, lifting and twisting movements of the back increases the pressure on the disc, thus injuring it. (10) Repetitive exercises and incorrect back posture in the early life can lead to regression of the disc nucleus, thus reducing the pressure (10), also working in fields where physical load is a daily activity is correlated with developing LDH (11).

Some theories suggest that the higher incidence in male LDH (Lumbar Disc Herniation) is a direct correlation with the harder labour that males perform in day to day activity and workplace. (12)

Lumbar disc space narrowing is also correlated through morphological and biomechanical research to lumbar workload, varying from country to country (13).

The debate still exists between researchers whether or not occupational loading and disc degeneration are connected, some of them finding modest results in exploring the correlation between the two (14). 
Our pervious paper came as a response to the many cases of young male adult population and male adolescents which addressed the rehabilitation units with lumbar sciatica and lumbar disc herniation as a result of exercising incorrectly at the gym. Reading many papers dedicated to this subject, we found some papers which addressed the issue of an elaborate rehabilitation plan to start work out again after healing from disc herniation (15), but not so many about preventing it.

Thus, we decided to start an awareness campaign through fliers to the patients which frequents the gym and address our unit, and also give fliers for them to take to their gym.

The fliers consisted in simple pictures and explanations to correct some possible wrong movement which the male subjects may do at the gym, based on the research of the most common types of exercises they make (16).

The flier included postures which the subject can correct (Figures 1 to 5) and exercises that are harmful to the lower back and how they can replace them with less harmful ones (Figures 6 and 7).
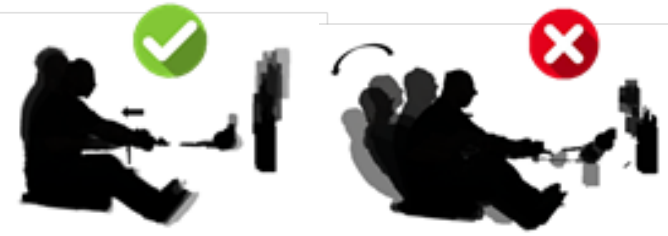

Fig. 1. Pulling weights with the lower back instead of the arms muscles can cause in time lumbar complications. To correct this, keep your back straight and pull weights with your arms.
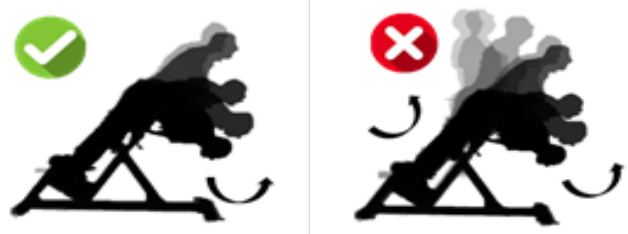

Fig. 2. Hyperextension is often a possible cause or complication of lumbar disc hernia, thus it must be controlled or evaded.

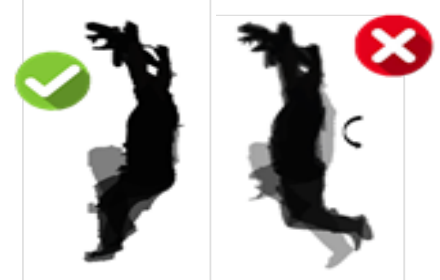

Fig. 3. When doing exercises for the abdomen it is very important to control the back muscles in order to prevent future lumbar pain.
Fig. 4. When lifting weights over the head it is necessary to prepare the muscles with lower weights first, and always control the back muscles. It also may be useful to use a back brace.
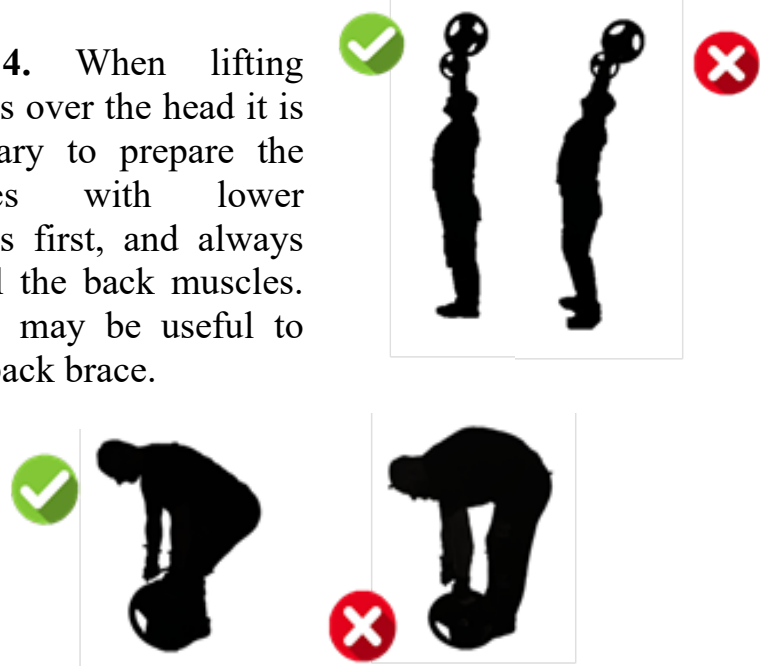

Fig. 5. When lifting weights from the floor, it is necessary to adopt a straight back position and to bend the knees to prevent disc herniation. It also may be useful to use a back brace.
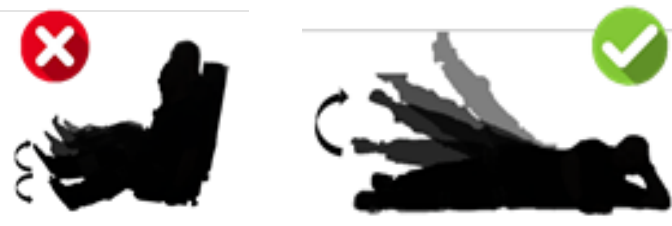

Fig. 6. Abduction and adduction exercises on the specific machine can cause strain on the lower back and lead in time to disc herniation. It is advisable instead to do simple lateral lifting of the leg in repeated sequences.
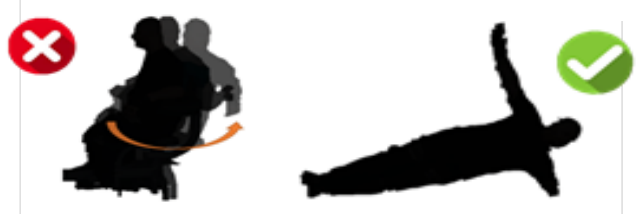

Fig. 7. Using the torso rotation machine for improving lateral abdominal muscles can affect the inner pressure of the disc. It is advisable to use different exercises, for example lateral plank.

\section{$2 \quad$ Material and Method}

To further our awareness campaign, we developed a questionnaire to help us understand the young populations' exposure and we distributed it to various gyms in Bucharest.

The questionnaire has simple questions, it is anonymous and it takes a few minutes to answer, so that the responders are more compliable to answer it. The responder has only to circle the age group which he is in and also circle the YES or NO answer to the 15 questions (Figure 8).

Fig. 8. The original version of the 15 Questions Disc Herniation Prevention at The Gym Questionnaire - in Romanian language. 


\section{CHESTIONARUL PREVENTIEI HERNIEI DE DISC IN SALA DE FORTA}

VA RUGAM SA RASPUNDETI LA INTREBARILE URMATOARE INCERCUIND RASPUNSUL PE CARE IL CONSIDERATI APLICABIL IN CAZUL DUMNEAVOASTRA

$\begin{array}{llllll}\text { INCERCUITI CATEGORIA DV DE VARSTA } & 20-25 & 26-30 & 31-35 & 36-40 & >40\end{array}$

1. Faceti incalzirea inainte sa va apucati de programul dumneavoastra DA NU normal de exercitii?

2. Folositi incarcare progresiva cand ridicati greutati?

3. Faceti genoflexiuni cu haltera pe umeri?

4. Tineti spatele drept si va aplecati din genunchi atunci cand ridicati greutati de jos?

5. Repetarile exercitiilor se fac in ritm alert?

6. Cand faceti exercitii de ridicarea greutatilor deasupra capului tineti spatele drept?

7. In cadrul exercitiile dumneavoastra faceti des hiperextensia spatelui?

8. Folositi centura atunci cand ridicati greutati?

9. Faceti exercitii de rotatie pentru muschii abdominali laterali?

10. Folositi aparatul cu greutati pentru muschii abductori si adductori?

11. Ati avut dureri lombare vreodata dupa antrenament?

12. Daca ati avut dureri, ati facut pauza de la antrenament urmatoarele zile?

13. Daca ati avut dureri lombare, $v$-ati adresat unui medic? 14. V-ati informat pe cont propriu referitor la hernia de disc?

15. Exercitiile la sala de forta le faceti pe cont propriu fara sa va examineze sau informeze cineva inainte?

The 15 questions are as followed:

1. Do you do warm-up before starting your normal exercise program?

2. Do you use progressive charging when you lift weights?

3. Do you do knee-bends with weights over your shoulders?

4. Do you keep your back straight and bend your knees when you lift weights from the floor?

5. Do you repeat your exercises in an alert rhythm?

6. When you lift weights over your head do you keep your back straight?

7. Do you often do back hyperextension when you train?

8. Do you wear lower back brace when you lift weights?

9. Do you do horizontal body rotations in order to exercise your lateral abdominal muscles?

10. Do you use a weight-machine when exercising your abductor and adductor muscles?

11. Have you ever had low-back pain after your training?

12. If you did have lower back pain, did you stop your exercise for the next few days?

13. If you did have lower back pain, did you go to see a doctor?

14. Did you research on your own about disc herniation?

15. Before training at the gym, do you ask a specialist for advice?

\section{$3 \quad$ Results and discussions}

We had 89 responders distributed on age categories thus: 20 to 25 years old $-21 \%, 26$ to 30 years old $-24 \%, 31$ to 35 years old $-19 \%, 36$ to 40 years old $-22 \%$ and over 40 years old $-14 \%$ (Figure 9) CATEGORY

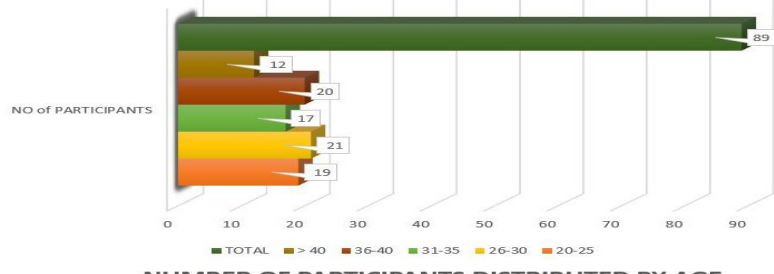

NUMBER OF PARTICIPANTS DISTRIBUTED BY AGE

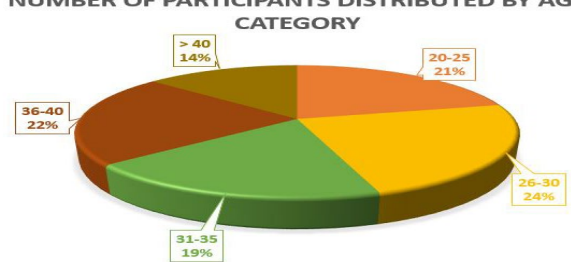

Fig. 9. Distribution of the responders to the 15 Questions Disc Herniation Prevention at The Gym Questionnaire by their age category plank

Each age category respondents had particularities to their replies. It can be observed that the lower the age category goes, there are fewer beneficial answers to the questions: over 40 years old groups' beneficial replies are $57.7 \%, 36$ to 40 years old groups' beneficial replies are $51.3 \%, 26$ to 30 years old groups' beneficial replies are $43.17 \%$ and the beneficial replies for the age group 20 to 25 years old are $37.9 \%$. (Figure 10)

Fig. 10. All answers to the 15 Questions Disc Herniation

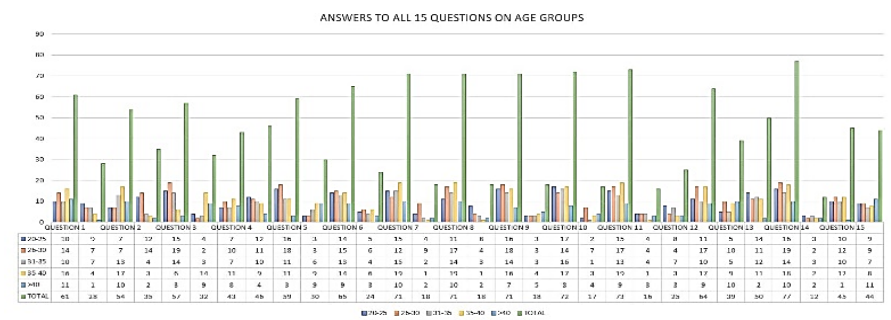

Prevention at The Gym Questionnaire distributed by their age category

The total number of beneficial responses from all the participants varied depending on the question. The most beneficial responses were given to the questions $1,2,6,8$ and 14 which translates that the subjects are aware to warm up before training, charge their weights progressively, keep their back straight when they lift weights above their heads, they wear back brace and they researched on their own about disc herniation.(Figure 11a)

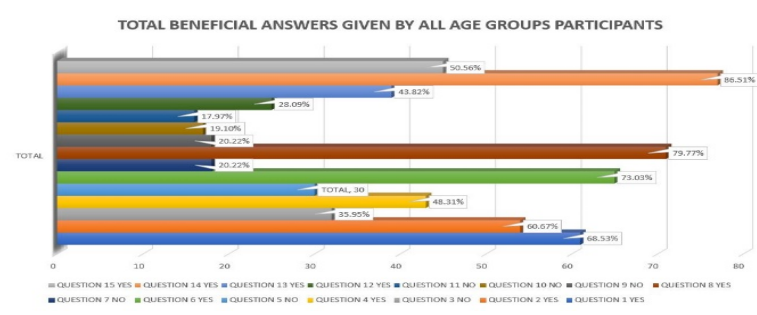

Fig. 11a. total beneficial answers given by the responders on the 15 Questions Disc Herniation Prevention at The Gym Questionnaire 
On the other hand, the majority of wrong answers where to the questions $3,5,7,9,10,11$ and 12 which means that subjects make mistakes when training at the gym: they do knee-bends with weights over their shoulders, they repeat their exercises in an alert rhythm, they do back hyperextension when they train, they do horizontal body rotations in order to exercise their lateral abdominal muscles, they use a weight-machine when exercising their abductor and adductor muscles and they had lowback pain their your training. (Figure 11b)

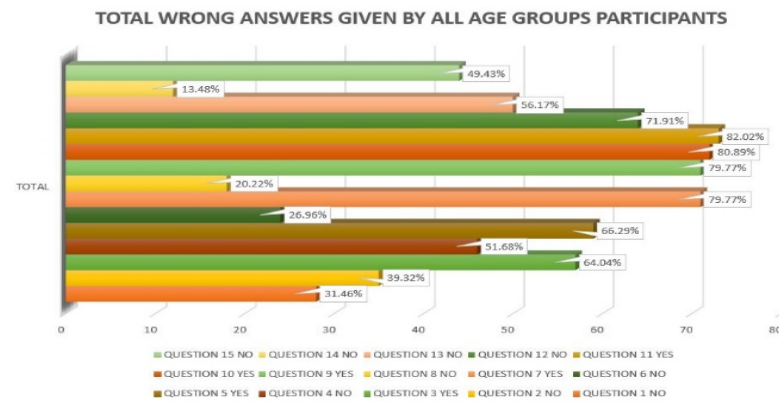

Fig. 11b. total wrong answers given by the responders on the 15 Questions Disc Herniation Prevention at The Gym Questionnaire

\section{Conclusions}

The data collected showed that most of the young male adults which frequent the gym are not fully prepared with enough knowledge in order to do certain exercises without risking lumbar disk herniation. The age group distribution showed that the older the population gets, the more careful it is when doing exercises.

The results not being very encouraging, we must continue our awareness campaign in this category of population in order to reduce the number of young patients with LDH.

\section{References:}

1. Fjeld OR, Grøvle L, Helgeland J, Småstuen MC, Solberg TK, Zwart JA, Grotle M. Complications, reoperations, readmissions, and length of hospital stay in 34639 surgical cases of lumbar disc herniation. Bone Joint J. 2019 Apr;101-B (4):470-477

2. Takatalo, JaniKarppinen, et all. Prevalence of Degenerative Imaging Findings in Lumbar Magnetic Resonance Imaging Among Young Adults, Spine: July 15, 2009 - Volume 34 Issue $\quad 16 \quad-\quad p \quad 1716-1721$ doi: 10.1097/BRS.0b013e3181ac5fec

3. Ma D, Liang Y, Wang D, et al. Trend of the incidence of lumbar disc herniation: decreasing with aging in the elderly. Clin Interv Aging. 2013; 8:1047-1050. doi:10.2147/CIA.S49698

4. Yin-gang Zhang, Zhengming Sun, Zhi Zhang, Jian Liu, Xiong Guo. Risk factors for lumbar intervertebral disc herniation in Chinese population: a case-control study. Spine (Phila Pa 1976) 2009 Dec 1; 34(25): E918-E922. doi: 10.1097/BRS.0b013e3181a3c2de

5. N. Matveeva, J. Zivadinovik, M. Zdravkovska, S. Jovevska, B. Bojadzieva. Histological composition of lumbar disc herniations related to the type of herniation and to the age.

\section{Bratisl Lek Listy. 2012; 113(12): 712-717}

6. Treatment of the aneurysmal bone cyst by percutaneous intracystic sclerotherapy using ethanol ninety five percent in children. Ulici A, Florea DC, Carp M, Ladaru A, Tevanov I. Int Orthop. 2018 Jun;42(6):1413-1419. doi: 10.1007/s00264-018-3841-y. Epub 2018 Feb 28. PMID 29492610

7. Aggressive development of an aneurysmal bone cyst of the proximal femur in a paediatric patient: a case report. Ulici A, Sterian AG, Tevanov I, Carp M, Dusca A, Cosma D. J Int Med Res. 2018 Jan;46(1):538-545. doi: 10.1177/0300060517722244. Epub 2017 Aug 23. PMID: 28835150

8. Surgical Treatment of an Aneurysmal Bone Cyst with Avascular Bone Graft. Ulici A, Nahoi C, Carp M, Fodor I, Dinu C. Chirurgia (Bucur). 2017 Mar-Apr;112(2):172-177. doi: 10.21614/chirurgia.112.2.172. PMID: 28463677

9. Hasvik E, Iordanova Schistad E, Grøvle L, Julsrud Haugen A, Røe C, Gjerstad J. Subjective health complaints in patients with lumbar radicular pain and disc herniation are associated with a sex - OPRM1 A118G polymorphism interaction: a prospective 1-year observational study. BMC Musculoskelet Disord. 2014; 15:161. Published 2014 May 18. doi:10.1186/1471-2474-15-161

10. Ma D, Liang Y, Wang D, et al. Trend of the incidence of lumbar disc herniation: decreasing with aging in the elderly. Clin Interv Aging. 2013; 8:1047-1050. doi:10.2147/CIA.S49698

11. M. K. Ahsan, T. Matin, M. I. Ali, M. Y. Ali, M. A. Awwal, N. Sakeb. Relationship between physical work load and lumbar disc herniation. Mymensingh Med J. $2013 \mathrm{Jul}$; 22(3): 533-540

12. Kim YK, Kang D, Lee I, Kim SY. Differences in the Incidence of Symptomatic Cervical and Lumbar Disc Herniation According to Age, Sex and National Health Insurance Eligibility: A Pilot Study on the Disease's Association with Work. Int J Environ Res Public Health. 2018;15(10):2094. Published 2018 Sep 25. doi:10.3390/ijerph15102094

13. Audrey Petit, Yves Roquelaure. Low back pain, intervertebral disc and occupational diseases. Int J Occup Saf Ergon. 2015; 21(1): 15-19. doi: 10.1080/10803548.2015.1017940

14. Macedo LG, Battié MC. The association between occupational loading and spine degeneration on imaging - a systematic review and meta-analysis. BMC Musculoskelet Disord. 2019:20(1):489. Published 2019 Oct 27. doi:10.1186/s12891-019-2835-2

15. Vangelder LH, Hoogenboom BJ, Vaughn DW. A phased rehabilitation protocol for athletes with lumbar intervertebral disc herniation. Int J Sports Phys Ther. 2013;8(4):482-516

16. Teoibas-Serban D, Stan V, Blendea D. Prevention of lumbar disc herniation in young adult population: a practical approach. Balneo Research Journal. 2019; 10 (3):416 DOI: http://dx.doi.org/10.12680/balneo.2019.276 P 